\title{
REFERENCES
}

1. Bakhtin, M. (1979). Aesthetics of verbal creativity. M. [in Russian]

2. Vygotsky, L. (1986) Psychology of art / preface. A. Leontiev; Comments L. Vygotsky, V. Ivanova; total ed. V. Ivanova. 3rd ed. M.: Art. [in Russian]

3. Ilyin, E. (2009) Psychology of creativity, creativity, giftedness. SPb.: Peter. [in Russian]

4. Kirnarskaya, D. (2004) Psychology of special abilities. Musical Abilities / Preface G. Rozhdestvensky. M : Talanta-XXI century. [in Russian]

5. Kovaleva, G. (2002) Interrelations of cognitive, personal and neurodynamic characteristics of creativity: diss. on competition uch. degree of candidate psychologist. Sciences: [spec.] 19. 00. 01 - general psychology, personality psychology, history of psychology / Perm State Institute of Art and Culture. Perm. [in Russian]

6. Lotman, Yu.(2000) Autocommunication: «I» and «Other» as addressees (On two communication models in the culture system). Lotman Y. Semiiosphere. St. Petersburg: «Art-SPB». P. 163-177. [in Russian]

7. Torshina, K. (1998) Modern Studies of the Problem of Creativity in Foreign Psychology. Questions of psychology. No. 4. P. 123-133. [in Russian]

8. Yakovlev, V. (1999) Philosophical principles of creativity. Bulletin of Moscow University. Series 7, Philosophy. № 3. P. 43-51. [in Russian]

Стаття надійшла до редакції 20.12.2017

УДК 781.5

DOI: $10.31723 / 2524-0447-2018-26-52-62$

Федорова Олександра Валентинівна

https://orcid.org/0000-0002-6488-869X

здобувач кафедри музики і музичної етнографії

Одеської національної музичної академії ім. А. В. Нежданової, музичний редактор радіостаниї «Гармонія Світу», м. Одеса fedorova_oleksandra@ukr.net.

\section{КАТЕГОРІЯ «КЛАСИЧНЕ» В МАСОВОМУ СУСПІЛЬНОМУ СПРИЙНЯТТІ: ІСТОРИЧНИЙ І СУЧАСНИЙ ПОГЛЯД}

Мета роботи полягає у визначенні категорії класичного як поняття в широкому сенсі слова в сучасній суспільній свідомості. Багатогранний зміст поняття «класичного» має на увазі можливість широкого використання як в області предметного і матеріального аналізу речей, так i для аналізу нематеріальних: духовних, естетичних, культурних та інших цінностей. Методи дослідження - історико-логічний, структурнофункціональний, які дозволили проаналізувати і розкрити основні сторони досліджуваної категорії. Наукова новизна роботи полягає в розширенні

(C) Федорова О. В., 2018 
уявлень про значення категорії класичного. Запропоновано якісні складові категорії класичного, відокремлено фактори, які формують смисловий зміст поняття «класичне»: 1. Гармонія; 2. Об'єктивна краса; 3. Ідеал; 4. Простота і доступність розуміння форми; 5. Зміст думки в певній формі; 6. Втілення реалістичної краси. Ряд чинників і визначень повинні бути присутніми при смисловому використанні слова «класичне»: 1. Закінчене творіння думки, предмета має видиму, визначену чутну, відчутну і певну людиною (суспільством) форму як «класичне». 2. Незмінність існуючого «класичного» творіння, яке відноситься до певного часу створення. 3. Простота єдиної форми, в якій зібрано зміст всіх якісних складових визначення «класичного». 4. Історичний час існування «класичного» творіння. Висновки. Рамки використання терміна який фактично є догматичним $i$ прийнятим у світовій практиці, підкоряються потребам суспільства івикористовуються в сучасному просторі як частина культурної спадщини. Сутність категорії «класичне» двоїста: з одного боку, «зразковий» - це певний абсолют і ідеал, який було виміряно $і$ затверджено історичним часом його існування, з іншого - це зразок, який дає можливість для подальшого творчого розвитку та створення нових зразків.

Ключові слова: класика, класичне, гармонія, еталон, класична форма.

Fedorova Alexandra Valentinovna, degree-seeking of the Department of Music and Music Ethnography of the Odessa National A. V. Nezhdanova Academy of Music, Musical editor of the «Harmony of the World» radio station.

The category "classical» in the mass public perception: a historical and modern view.

The aim of the work is to define the category of the classical as a concept in the broad sense of the word in the modern public consciousness. The multifaceted meaning of the concept of «classical» implies the possibility of widespread use both in the field of object and material analysis of things, and for the analysis of intangible: spiritual, aesthetic, cultural and other values. The methods of research are historical-logical, structural-functional, which allowed to analyze and reveal the main aspects of the category under study. The scientific novelty of the work is to expand the notion of the significance of the classical category. The qualitative components of the classical category are proposed: 1. Harmony; 2. Objective beauty; 3. The ideal; 4. Simplicity and accessibility of understanding forms; 5. The content of thought in a certain form; 6 . Realization of realistic beauty. A number of factors and definitions should be present in the semantic use of the word «classical»: 1. The finished creation of thought, the object has a visible, audible, tangible and defined form («society») as «classical». 2. The invariance of the existing «classical» creation, which refers to a certain time of creation. 3. The simplicity of a single form, in which the content of all qualitative components of the definition of «classical» is collected. 4. The historical time of the existence of the "classical» creation. Conclusions. The framework for using the term, which is actually dogmatic and accepted in world practice, is subject 
to the needs of society, and is used in the modern space as part of the cultural heritage. The essence of the category «classical» is dual: on the one hand, «exemplary» is a certain absolute and ideal that was measured and approved by the historical time of its existence, on the other it is a model that gives an opportunity for further creative development and creation of new samples.

Keywords: classic, classical, harmony, standard, classical form.

Фёдорова Александра Валентиновна, соискатель кафедры музыки и музыкальной этнографии Одесской национальной музыкальной академии им. А. В. Неждановой, музыкальный редактор радиостанции «Гармония мира»

Категория «Классическое» в массовом общественном восприятии: исторический и современный взгляд

Цель работы состоит в определении категории классического как понятия в широком смысле слова в современном общественном сознании. Многогранный смысл категории «классического» подразумевает возможность широкого использования как в области предметного и материального анализа вещей, так и для анализа нематериальных: духовных, эстетических, культурных и других ценностей. Методы исследования историко-логический, структурно-функциональный, которые позволили проанализировать и раскрыть основные стороны исследуемой категории. Научная новизна работы заключается в расширении представлений о значении категории классического. Предложены качественные составляюшие категории классического: 1. Гармония; 2. Объективная красота; 3. Идеал; 4. Простота и доступность понимания формы; 5. Содержание мысли в определённой форме; 6. Воплощение реалистической красоты. Ряд факторов и определений должны присутствовать при смысловом использовании слова «классическое»: 1. Законченное творение мысли, предмета имеет видимую, слышимую, ощутимую и определенную человеком (обществом) формукак «классическое». 2. Неизменность существующего «классического» творения, которое относится к определённому времени создания. 3. Простота единой формы, в которой собрано содержание всех качественных составляющих определения «классического». 4. Историческое время существования «классического» творения. Выводы. Рамки использования термина, который фактически является догматическим и принятым в мировой практике, подчиняются потребностям общества и используется в современном пространстве как часть культурного наследия. Сущность категории «классическое» двойственна: с одной стороны, «образиовый» - это определенный абсолют и идеал, который был измерен и утвержден историческим временем его существования, с другой это образеи, который дает возможность для дальнейшего творческого развития и создания новых образцов.

Ключевые слова: классика, классическое, гармония, эталон, классическая форма. 
Актуальність теми дослідження полягає в необхідності усунення протиріччя: наявність поширення терміна «класичне» 3 давніх часів і одночасно - невиявлених складових цього поняття.

Мета роботи - у визначенні категорії класичного як поняття в широкому сенсі слова в сучасній суспільній свідомості. Багатогранний зміст поняття «класичного» має на увазі можливість широкого використання як в області предметного і матеріального аналізу речей, так і для аналізу нематеріальних: духовних, естетичних, культурних та інших цінностей.

Наукова новизна роботи полягає в розширенні уявлень про значення категорії класичного. Запропоновано якісні складові категорії класичного, відокремлено фактори, які формують смисловий зміст поняття «класичне». Якщо поняття «класичне» дослівно означає «зразкове», то його сутність буде двоякою. 3 одного боку, «зразковий» - це певний абсолют і ідеал, який був виміряний і затверджений історичним часом його існування, з іншого - це зразок, який надає можливість для подальшого творчого розвитку та створення нових зразків. Це цілком закономірно, адже ми вже зауважили, що сукупність понятійних категорій «класичного» визначається суспільством, а воно змінюється і еволюціонує. Для сучасного суспільства класичною стає форма існування предмета, затверджена суспільством протягом століть.

Виклад основного матеріалу. «Класика» $\mathrm{i}$ «класичне» - давно відомі і вкорінені термінологічні категорії мислення в соціокультурному і комунікативному просторі суспільства. У сучасній повсякденності вони продовжують успішно існувати, більше того, залишаючи за собою своє смислове значення і актуальність. Розглядаючи аспекти категорії «класичного», ми визнаємо загальну абстрактність цього поняття. По суті - багатогранний сенс, закладений в понятті «класичного», дає йому право називатися певним «абсолютним словом».

Дане поняття має на увазі можливість широкого використання як в області предметного і матеріального аналізу речей, так і для аналізу нематеріальних: духовних, естетичних, культурних та інших цінностей, в спробі підкреслити їх видиму, чутну, або відчутну досконалість. Так само, це «абсолютне слово» дозволяє теоретично виміряти і визначити якість існування створеної людиною матерії: від простих побутових речей до творів мистецтва. Застосовувані до всіх форм творіння людини, ці словесні визначення - сукупності категоріальних смислів $-€$ понятійним абсолютом для визначення створеної та існуючої форми матерії. 
Об’єктом визначення категоріальних понять «класичного» є суспільство. Поняття «класичного» як зразка і звання, визначається і встановлюється численними оцінками, громадською думкою, а також часом існування тих чи інших культурних цінностей в історії. Користуючись понятійними категоріями, збираючи їх в єдине ціле поняття (класичного) як зразка, що застосовуються при визначенні цінності існуючої спадщини, ми можемо говорити про поняття «класичного» як про існуючу форму передачі культурної спадщини.

Категорія «класичного» виходить 3 фундаментальних історичних усталених категорій знань точних і прикладних наук часів Стародавньої Греції. Визначення класичного походить від лат. classicus зразковий, і віднесено до V-VI століття до н. е. Класичною Грецією А.-М. Бюттен називає період «между началом греческой истории и приходом к власти Александра Македонского» [2, 5] (тобто до 340 р. до н. е.). В цьому періоді О. Ф. Лосев виділяє ранню, високу та пізню класику [6].

Свій розвиток «класичне» здобуло в філософських працях Піфагора і його школи. Як відомо, філософські вчення Піфагора, були досить широкі і зачіпали різні форми людського буття. Для цілісного пізнання навколишнього світу Піфагор використовував математичні обчислення, застосовуючи вимір до пізнання і вивчення навколишнього простору [4].

Виникнення класичного як зразкового торкнулося всіх сфер розвитку еллінського суспільства: точні науки, філософія, філологія, мистецтво, юриспруденція. Створюються перші університети і школи, які дають «зразкові знання» у всіх сферах людського пізнання. Цінність «класичної» освіти полягала не тільки в наданні знань у вузькій професійній сфері, але й в цілісному розвитку всіх областей пізнання, що включають в себе: духовні, культурні, релігійні, історичні тощо. Так, скажімо, відома трагедія Евріпіда понині є зразком сюжетної схеми трагедії [3].

Найважливішим досягненням культури Греції часів ранньої, високої та пізньої класики [6] було не тільки навчання фактичним знанням в точних науках, а й розвиток індивідуума у «вищих» духовних сферах життя і творчості. Саме сукупність знань, які підносилися як для вивчення і пізнання світу, так для всебічного розвитку духовної сфери особистості, заклала фундаментальну основу форми передачі знань і мислення, необхідну для розуміння матеріального повсякденного життєвого простору і духовних ідеалів гар- 
монії, краси людини та їі творінь. Таким чином був збережений баланс між освітою матеріальною і духовною. Стародавня Греція стає прикладом втілення ідей прекрасного розвиненого «класичного» суспільства, яке шляхом навчання розвиває культуру і освіченість своїх громадян. Надалі еллінська культура і її зразки, створені в усіх сферах життя людини, стають еталонами для наслідування іншими культурами і народами.

Дослідження античної - класичної (за існуючим сучасним визначенням) культури, іії різних областей, актуально і в теперішній час (наприклад: [5; 7]). Поняття «класичного» як зразкового успішно існує в наші дні. У «Великому тлумачному словнику сучасної української мови» до терміну «класичний» віднесено десятки областей науки та культури (наприклад: класична акустика, класична електродинаміка, класична космологія, класична механіка, класична статистика, класична теорія, класична фігура, класична фізика, класична цефеїда, класичне доведення, класичне наближення і т. ін.) [6].

Таке довге існування цього поняття криється в його суті, а саме: в тих смислових еталонних значеннях, які формують це визначення. Так, еталонне «класичне» стає сукупністю зібраних понять, які використовуються для його визначення й тлумачення. Розглядаючи сучасну культуру і суспільне життя, ми констатуємо їх переродження. Такі перетворення суспільства в першу чергу пов'язані з переважанням матеріального світу над духовним. Освіченість, культура і духовність йдуть на другий план, поступаючись місцем матеріально простим речам, які нам потрібні в повсякденному житті для існування. Це впливає на загальний рівень духовної культури: інформаційне поле отриманої освіти, впритул наближаючи до матеріальної цінності предметного світу, віддаляє від піднесеного «вічного». Сучасне суспільство навчає бути частиною матеріального світу, розвиток особистості як духовного індивідуума сходить нанівець. Ця тенденція духовного занепаду у XX столітті була висловлена Г. Гессе: «А проте в часи реформації духовного життя, яка почалася в двадцятому сторіччі і спадкоємцями якої ми стали, цей давній, високий ідеал був майже цілком утрачений» $[1,4]$.

Оцінюючи існування даних категоріальних визначень класичного в сучасності, варто вважати, що актуальність цих визначень не втрачена. Вона полягає в понятійних категоріях, що складають їх сутність: ідеалі, незмінності, еталоні краси форми і змісту, гармонії, простоті сприйняття. Кожна категоріальна форма в свою чергу має свій ши- 
рокий понятійний сенс. Значення кожного з них є усталеною в історичному контексті, самостійною змістовною одиницею і оціночною категорією класичного одночасно.

При розгляді понятійних категорій «класичного», які формують це складне поняття, ми неодмінно повинні торкнутися і самих «визначень - інструментів», якими ми користуємося для констатації даного поняття. Ми використовуємо такі смислові категорії:

1. Гармонія;

2. Об'єктивна краса;

3. Ідеал;

4. Простота і доступність розуміння форми;

5. Зміст думки в формі;

6. Втілення реалістичної краси.

Поняття «гармонії» є найбільш широким і духовним поняттям. Гармонію як поняття в широкому сенсі досить важко об'єктивно сформулювати і визначити. Значення цього поняття має на увазі сукупність багатьох елементів, як існуючих матеріальних речей, так i незримих духовних. Це є певний ідеальний стан, в якому може перебувати людина. Він створює довколишній простір: духовне, культурне, побутове і матеріальне. Гармонія - це поняття відчуття внутрішнього духовного світу людини і оточуючого ії простору, яке так само вона може відчути, створюючи, споглядаючи і відчуваючи його. Гармонія - це певний високий стан душі, матеріального або духовного порядку, при розумінні якого у свідомості виникають відчуття насолоди. У матеріальному просторі (створеному людиною) воно виражається в існуючому предметі споглядання.

Поняття «об’єктивної краси» є цілком матеріальним поняттям, адже для його визначення ми повинні побачити чи почути, а значить, повинен бути якийсь об'єктивно існуючий предмет. Ця смислова категорія є матеріальною, суб'єктивною і змінною. Визначення цього поняття залежить від індивідуально закладених культурних, релігійних, історичних тимчасових і громадських параметрів існування індивідуума. Визначення «об'єктивної краси» - є категорія історичної індиферентності. Незважаючи на відкрите протиріччя між поняттями «об’єктивності» і «індиферентності», категорія «об’єктивної краси» підвладна громадським оцінками і може змінюватися в історичному контексті.

Ідеал - поняття абсолюту. Ця смислова категорія є категорією, що існує для оцінки сукупності зібраних особистісних понять (через 
суб’єктивний, індивідуальний досвід), і поняттям, що створене для оцінки ціннісних ідеалів мас. Ідеалом (громадським) прийнято називати якийсь загальноприйнятий зразок, абсолютна цінність якого не може бути поставлена під сумнів, оскільки вона визначається самим суспільством.

Простота і доступність форми потрібна для аналізу споглядання створеного предмета. Основою всього є форма та іï незмінність. Оскільки звання класичного присвоюється суспільством, предмет оцінки має бути зрозумілим для багатьох, а для цього потрібна доступність в розумінні його значення. Простота і доступність форми дозволяє майже моментально визначати ііі наявність, тому що велика кількість елементів змушує більш поглиблено аналізувати предмет оцінки, і не кожен індивідуум здатний провести поглиблений аналіз, а значить і оцінити красу і гармонію предмета. Будучи продуктом думки і виходячи з неї, форма стає матеріально існуючим творінням людини. Своїм існуванням в просторі і незмінністю вона є формою існування або буття в просторі. Вона $є$ першоджерелом в осмисленні, і грунтом для визначення та аналізу їі сутності. Закінченість форми, iii певна будова дає впорядкованість просторових елементів зібраних в ній, і тільки тоді вона підвладна осмисленню, адже відсутність форми є хаос і відсутність впорядкованості та гармонії.

Класична форма - еталонна форма сукупності гармонії, краси і простоти. Простота і зрозумілість існуючого предмета оцінки так само є певним критерієм у присвоєнні звання «класичного». Виявляючи предмет і його існування, він повинен бути зрозумілим і гармонійно простим, доступним для суспільства. Незмінність форми, iï постійна присутність в просторі як єдиної одиниці (яка може бути структурована з безлічі елементів і наділена певними якостями) дозволяє нам осмислити і проаналізувати ії характеристики, які ми використовуємо для визначення оціночної сутності форми існуючого творіння. Не менш важливим є і зміст «класичної» форми.

Зміст форми визначається її можливостями і впливом на людину. Визначаючи шляхом осмислення або емоційного сприйняття зміст, ми можемо виявити і виділити особливості змісту даної форми, іiі характерні відмінні риси, що дозволяє нам зарахувати ії до певних і попередньо визначених категорій «матеріального» або ж «духовного» порядку і допомагає визначити іiї функціональну цінність для подальшого використання людиною. У високих зразках класичної культурної спадщини духовна суть предмета мистецтва - філосо- 
фії, культури, поезії, музики, танцю і скульптури, створена грецькими класиками, завжди має просту і зрозумілу форму. Тут якнайкраще підходять слова Евріпіда, сказані про простоту: «Слова истины просты» [3].

Ці смислові категорії визначення не можуть втратити актуальність, оскільки ці поняття споріднені з вічним питанням людського існування. До роздумів про них ми повертаємося постійно: в спробах визначення, переосмислення та аналізу. В рамках нашої роботи ми пропонуємо своє визначення загального поняття класичного: класика (класичне) - еталонне слово для визначення параметрів існування зразків творіння людської думки (існуючих в просторі форм). Це сукупність образів і понять про красу, гармонію, досконалості і незмінності зібраних в єдиній простій існуючій формі (творінні), яка визначається суспільством, часом ії існуванням в історичному контексті.

Виходячи з цього поняття, ми можемо винести ряд факторів і визначень, які мають неодмінно бути присутніми при смисловому використанні слова «класичне»:

1. Створене і закінчене творіння думки, існуючий предмет (що має видиму, чутну, відчутну і визначену людиною (суспільством) форму як «Класичне»).

2. Незмінність існуючого «класичного» творіння (його постійну існуючу форму).

3. Зібраний в єдиній формі зміст, який відповідає всім смисловим категоріям визначення «класичного». Простота форми.

4. Час (критерій існування часу - це фактор, необхідний для визначення всіх вищевикладених положень для їх затвердження та зарахування до категорії «класичного»).

Фактор часу дозволяє нам визначити вірність оціночних суджень, відносно існуючої музичної формі, а також він потрібен для оцінки іiі існування, адже оцінка $-€$ осмислення людиною, а для осмислення потрібен час. Час виступає як в моментальній просторовій дії осмислення, так і в історичному контексті, що дозволяє встановити незмінні і загальні оціночні критерії для ряду існуючих в просторі зразків, створених людиною.

У сучасному світі поняття класичного зводитися до визначення його як однієї з форм існування культурної історичної цінності і спадковості, разом з іншими епохами і течіями: епохою Відродження, Просвітництва, романтизму, посткласицизму, модернізму, пост- 
модернізму, еклектики і сучасною культурою. Теоретично воно залишається зразком найвищого культурного ідеалу. Практично - стає одним зі стилів, що використовуються в усіх сферах людського життя. На сучасному етапі розвитку суспільства і його прагнення до глобалізації поняття класичного втрачає свою первісну філософію і структуру. В першу чергу за рахунок втрати прагнення до створення піднесених культурних цінностей і прагнення до особистісної свободи вибору. Оскільки час накладає свій відбиток, і життя - це єдність існування людини і суспільства, матеріального і духовного начал, така тенденція є цілком закономірною.

Узагальнюючи вищевикладене, ми бачимо що класичне як поняття існує в нашому сприйнятті, критерії оцінки цього поняття не змінюються, але з історичним прогресом розвитку суспільства рамки використання терміна «класичний» відходять від піднесеного «ідеального зразка», схиляючись до повсякденного матеріального простору. Фактор часу є одним з головних критеріїв визначення «класичного». Це ми можемо спостерігати відносно мистецтва як найвищого зразка людського творіння.

Підходячи до завершення наших роздумів про поняття «класичного», ми визначаємо його як поняття парадоксальне. 3 одного боку, класичне $є$ певною усталеною і незмінною понятійною формою, яка формувалася протягом багатьох століть, з іншого - спадкоємність і зміна поколінь дають можливість розширення рамок сприйняття терміна «класичний».

Висновки. Таким чином, ми бачимо, що рамки використання терміна, який фактично є догматичним і усталеним у світовій практиці, підкоряються потребам суспільства, і використовуються в сучасному просторі як частина культурної спадщини. Культура, як частина створеного людиною духовного простору, є певна тимчасова гра - гра поколінь в спробах створення свого бачення епохи. Класичне є певною абсолютною формою зразка, визнаного суспільством, і є високим званням і оцінкою, яка надається найбільш гідним творам людини. А значить, виділяє його і зберігає в історичній спадщині для наступних поколінь.

\section{СПИСОК ЛІТЕРАТУРИ}

1. Гессе Г. Гра в бісер : роман / пер. з нім. С. О. Поповича. Х. : Фоліо, 2001. $510 \mathrm{c}$.

2. Бюттен А.-М. Классическая Греция. М.: Вече, 2006. 384 с. 
3. Еврипид. Финикиянки / пер. с древнегреч. Иннокентия Анненского. Еврипид. Трагедии. М., 1980. Т. 2. С. 145-224.

4. Жмудь Л. Я. Пифагор и его школа (ок. 530 - ок. 430 гг. до н.э.). Ленинград. : Наука. Ленинградское отделение, 1990. 193 с.

5. Историко-философский ежегодник 2004. М.: Наука, 2005. 421 с.

6. Лосев А. Ф. История античной эстетики: в 8 томах. Т. 3: Высокая классика. М.: ООО «Издательство АСТ», 2000. 624 с.

7. Симпликий. Комментарий к четырём книгам трактата Аристотеля «О небе». Комментарий ко второй книге / пер. А. А. Россиуса. Историкофилософский ежегодник 2004. М.: Наука, 2005. С. 11-33.

\section{REFERENCES}

1. Hesse, G. (2001). The Glass Bead Game. Folio, 2001 [in Ukrainian].

2. Bütten, A.-M. (2006). Classical Greece. Moscow: Veche, 2006 [in Russian].

3. Evripid. (1980). Phoenicians. Translation from the Ancient Greek Innocent Annnes. Evripid. Tragedies M., Vol. 2. P. 145-224 [in Russian].

4. Jmul, L. (1990). Pythagoras and his school (about 530 - about 430 BC). Leningrad : «Science» Leningrad Branch [in Russian].

5. Historical and Philosophical Yearbook (2004). Moscow: Nauka [in Russian].

6. Losev, A (2000) History of ancient aesthetics (in 8 volumes). T. 3. High classics, M.: LLC «Publishing AST» [in Russian].

7. Simplicius, (2005) Commentary on the four books of Aristotle's Treatise On the Heavens. Commentary on the second book. Trans. AA Rusius. Historical and Philosophical Yearbook - 2004, Moscow: Nauka, P. 11-33. [in Russian]. 